\title{
Conopsoides Hitchcock 1858: an ichnological chimera of Acanthichnus and Bifurculapes
}

\author{
Patrick R. GetTY ${ }^{1}$ AND John BurnetT ${ }^{2}$ \\ 1. Department of Geology, Collin College, 2800 E. Spring Creek Parkway, Plano Texas 75074, USA \\ 2. Center for Advanced Studies in Mathematics and Natural Sciences, Collin College, \\ 2800 E. Spring Creek Parkway, Plano Texas 75074, USA \\ Corresponding author <pgetty@collin.edu $>$
}

Date received: 2 July 2019 gate accepted 24 October 2019

\begin{abstract}
THe ichnogenus Conopsoides, established in the Nineteenth Century, was differentiated from other ichnogenera by the presence of mounds of sediment associated with the tracks, but this characteristic is now considered an invalid ichnotaxobase by some invertebrate ichnologists. Consequently, Conopsoides has been compared to other ichnogenera in the Hitchcock collection in order to determine if other characteristics could be used to differentiate it. As a result, the morphologies exhibited by Conopsoides are seen in two other ichnogenera, Acanthichnus and Bifurculapes. Specifically, the morphologies seen in the type species, Conopsoides larvalis, are observed in Acanthichnus cursorius and Acanthichnus saltatorius, and therefore different specimens of Conopsoides larvalis are considered to belong to these two ichnospecies. Similarly, the morphology observed in Conopsoides curtus is observed in Bifurculapes laqueatus, so the former ichnospecies is considered a junior subjective synonym of the latter.
\end{abstract}

\section{RÉSUMÉ}

On différenciait l'ichnogenre Conopsoides, établi au cours du $19^{\mathrm{e}}$ siècle, des autres ichnogenres par la présence de monticules de sédiments associés aux traces, mais certains ichnologues des invertébrés considèrent désormais cette caractéristique comme une ichnotaxobase invalide. Les chercheurs ont en conséquence comparé le Conopsoides à d'autres ichnogenres à l'intérieur de la collection de Hitchcock afin de déterminer si d’autres caractéristiques pourraient servir à le différencier. Les morphologies que présente le Conopsoides ont ainsi été observées chez deux autres ichnogenres, l'Acanthichnus et le Bifurculapes. Les morphologies relevées chez l'espèce type, le Conopsoides larvalis, sont en particulier présentes chez l'Acanthichnus cursorius et l'Acanthichnus saltatorius, de sorte que différents spécimens de Conopsoides larvalis sont considérés comme des membres de ces deux ichnoespèces. Dans le même ordre d'idées, la morphologie observée chez le Conopsoides curtus est présente chez le Bifurculapes laqueatus, de sorte que l'ancienne ichnoespèce est considérée comme un synonyme subjectif plus récent de la seconde.

[Traduit par la redaction]

\section{INTRODUCTION}

In order for trace fossil names to be useful, they should communicate specific information about the biogenic structures to which they are applied (Rindsberg 2012). To that end, those who establish names for trace fossils should seek out meaningful characteristics (ichnotaxobases) to apply to the description of the trace fossils so that they can be differentiated from each other (Bertling 2007). In practice, however, what is considered a meaningful characteristic is subjective, and many different ichnotaxobases have been used in ichnology.
Recently, much progress has been made in standardizing what are considered valid ichnotaxobases. For invertebrate trace fossils, Bromley (1996) and many others (e.g., Pickerill 1994; Goldring et al. 1997; Bertling et al. 2006; Bertling 2007; Minter et al. 2007; Buatois and Mángano 2011) have proposed that names should be based on trace morphology, which is an expression of the maker's behavior. Most researchers (e.g, Trewin 1994; Bertling et al. 2006; Bertling 2007; Knaust 2012) agree that, for invertebrate trackways, the important ichnotaxobases should include the shape, dimensions, and spatial arrangement of the tracks, coupled with other features such as the presence or absence of drag marks. 
The lack of standard ichnotaxobases, e specially early in the history of ichnology, has led to a plethora of ichnotaxa, many of which are poorly defined and/or illustrated, and some of which are likely subjective synonyms of others (Häntzschel 1975; Pickerill 1994). Various researchers (e.g., Osgood 1970) have called for ichnotaxonomists to undertake the work of reevaluating invertebrate taxa in an attempt to reduce the number of unnecessary ichnogenera and ichnospecies. The invertebrate ichnotaxa described by Edward Hitchcock in the Nineteenth Century are among those that are badly in need of revision due to his excessive splitting of taxa (Olsen et al. 1992; Keighley and Pickerill 1998; Rainforth 2005; Minter and Braddy 2009).

Work has already begun, typically one taxon at a time, to address the taxonomy of Hitchcock's ichnotaxa (e.g., Minter et al. 2012; Lucas et al. 2013; Dalman and Lucas 2015; Getty, 2016, 2017, 2018; Goldstein and Getty, 2017), but given that Hitchcock established 31 ichnogenera and 60 ichnospecies, much additional work is necessary. The present study, which examines the ichnogenus Conopsoides, is a continuation of this ongoing effort to reevaluate Hitchcock's ichnotaxonomy.

Such ichnotaxonomic revisions have implications beyond the streamlining of vast taxonomic lists. For example, in a recent paleodiversity analysis, Buatois and Mángano (2018) used ichnodiversity, or the number of trace fossil types in a given geological assemblage or geological period, to assess the evolution of behavior through time. Excessive splitting of trace fossil morphologies based on minor morphological distinctions can skew the results of such analyses; this problem can be ameliorated through ichnotaxonomic revisions.

\section{GEOLOGICAL CONTEXT}

The specimens evaluated in this paper were found in the Deerfield Basin of southern New England (Figs. 1a-b). The sedimentary and igneous rocks that comprise the basin fill are part of the Late Triassic to Early Jurassic Newark Supergroup of eastern North America. The rocks formed as Pangea rifted prior to the opening of the Atlantic Ocean (Olsen 1978, 1997). Throughout this interval, the paleoclimate of the region was monsoonal (Parrish 1993), with a long dry season (Hubert 1978).

In the Triassic, basin subsidence was slow, and fluvial strata accumulated to form the Sugarloaf Formation (equivalent to the Passaic Formation, Sugarloaf Member of Weems et al. 2016). By the Early Jurassic, however, the crustal extension rate increased, causing faults on the eastern edge of the basin to coalesce to form an asymmetrical, east-dipping half graben (Schlische and Olsen 1990). Deposition changed from fluvial to predominantly lacustrine, concurrent with faster subsidence and border fault formation. The lacustrine deposits are represented by the Fall River beds and the Turners Falls Formation (Shuttle Meadow and East Berlin formations, respectively, of Weems et al. 2016). The lake deposits exhibit regularly repeating patterns of grey and black shale, formed in deeper permanent lakes, separated by red mud-

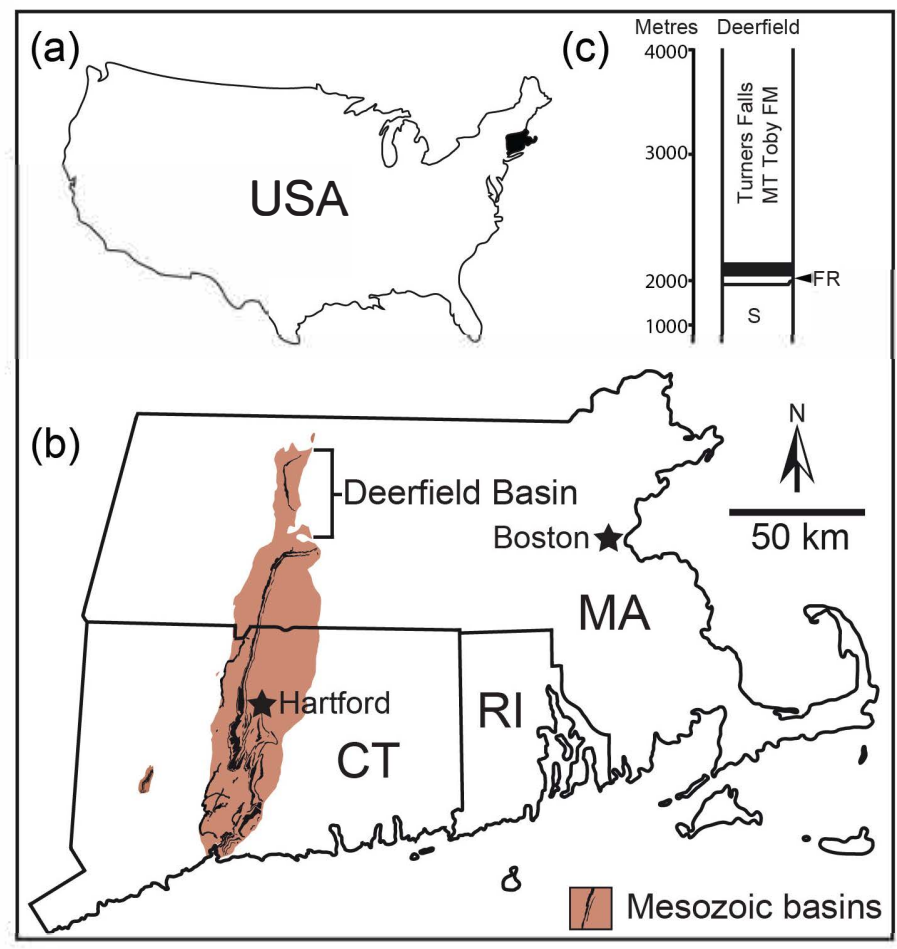

Figure 1. Geographical and geological context of the fossils evaluated herein. (a) Map of the contiguous United States with southern New England states shaded in black. (b) Map of the southern New England states including Connecticut (CT), Massachusetts (MA), and Rhode Island (RI), highlighting early Mesozoic basins. Igneous rocks are represented in black; sedimentary rocks are represented in brown. (c) Simplified stratigraphic columns of the Deerfield Basin. Abbreviations are: $F R=$ Fall River beds, $S=$ Sugarloaf Formation.

stone and sandstone formed in shallower ephemeral lakes. Olsen (1986) proposed that Milankovich-cycle-influenced climate changes account for the cyclicity of the lacustrine strata, but this hypothesis was recently questioned by Tan-ner and Lucas (2015). Along with rapid subsidence came a $600 \mathrm{ka}$ interval of basalt volcanism (Olsen et al. 1996). Olsen et al. (1992) suggested that the basin filled by Middle Jurassic times.

Hitchcock collected the material that he attributed to Conopsoides from Early Jurassic lacustrine beds of the Lily Pond locality (Hitchcock 1858, 1865), where rocks of the Turners Falls Formation are exposed (Fig. 1c). Lily Pond was considered by both Lull (1953) and Olsen et al. (1992) as among the most important of Hitchcock's sites because of the large number of well-defined vertebrate and invertebrate traces found there.

\section{MATERIALS AND METHODS}

The trackways examined during this study are housed at the Beneski Museum of Natural History (abbreviated as 
ACM) at Amherst College. The acronym ICH, following $\mathrm{ACM}$, indicates that specimens are part of the museum's ichnology collection. Trackways were photographed under low-angle light and measurements were taken from the photographs using the public-domain image-processing and analysis program ImageJ (Rasband 1997-2014). For Acanthichnus, measurements included trackway width, track length, angle to midline for the track, repeat distance between tracks, and distance between tracks (Fig. 2a). For Bifurculapes, measurements included track length, track width, angle to midline for the track, repeat distance between tracks, inner trackway width, and outer trackway width (Fig. 2b; see Getty 2016 for further explanations of these measurements). A morphometric analysis using track length and width was conducted to determine the uniqueness of Conopsoides curtus relative to Bifurculapes laqueatus.

We followed ichnotaxonomic guidelines proposed by Bertling et al. (2006) and Minter et al. (2007) when considering potential synonymies. For example, we considered synonymization justifiable for intergrading specimens when the different morphologies represent small variations within an ethological category, or when they represent minor substrate differences. Importantly, we follow Trewin (1994) and Bertling et al. (2006) in rejecting sediment mounds as a valid ichnotaxobase for arthropod trackways because the presence or absence of these features can be affected by substrate consistency and undertracking.
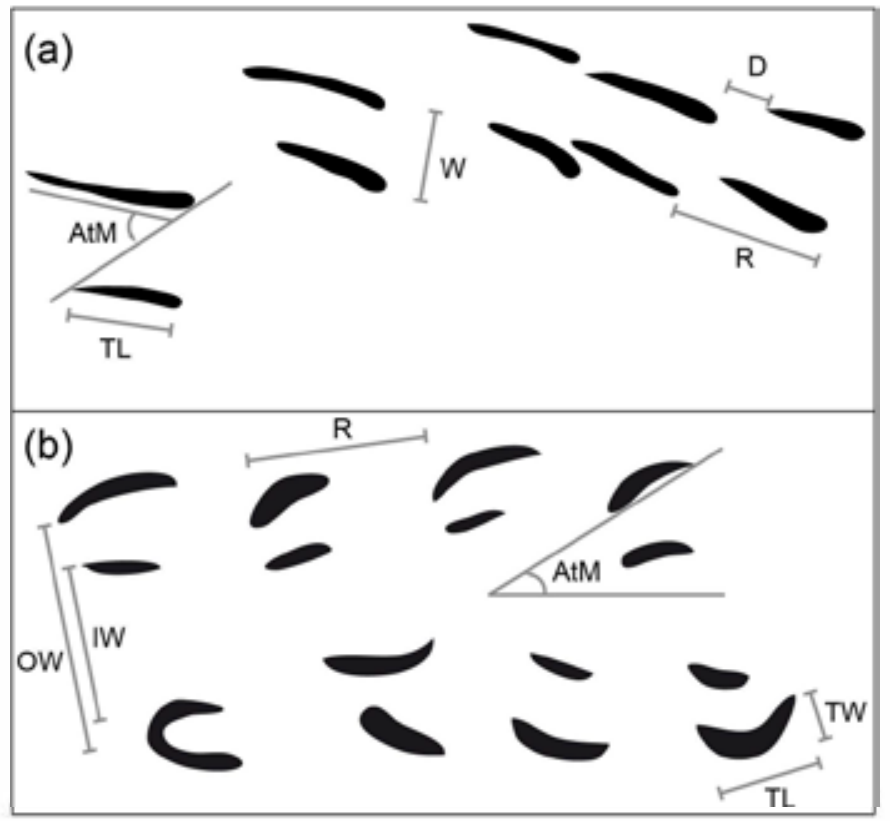

Figure 2. Trackway measurements utilized in this study. (a) Those for Acanthichnus, and (b) those for Bifurculapes. Abbreviations are: AtM = angle to trackway midline, $\mathrm{D}=$ distance between successive tracks, $\mathrm{IW}=$ inner trackway width, $\mathrm{OW}=$ outer trackway width, $\mathrm{R}=$ repeat (stride) distance, $\mathrm{TL}=$ track length, $\mathrm{TW}=$ track width, $\mathrm{W}=$ trackway width .

\section{SYSTEMATIC ICHNOLOGY}

\section{Ichnogenus Acanthichnus Hitchcock 1858}

(Figs. 3-5)

1858 Acanthichnus E. Hitchcock, p. 150.

1858 Conopsoides (in part) E. Hitchcock, p. 152, pl.29, fig. 6; pl. 30, fig. 4.

1865 Conopsoides (in part) E. Hitchcock, p. 15, pl. 6, fig. 4. 1889 Conopsoides (in part) C.H. Hitchcock, p. 119. 1915

Conopsoides (in part) Lull, p. 60-61.

1953 Conopsoides (in part) Lull, p. 45.

1975 Conopsoides (in part) Häntzschel, p. W52.

1997 Hamipes (in part); Bolliger and Gubler, p. 619, fig. 5.

2005 Conopsoides (in part); Rainforth, p. 840, fig. 5.20.

Type species. Acanthichnus cursorius Hitchcock 1858, designated by Lull (1953, p. 40).

Other species. Acanthichnus alatus Hitchcock 1865, Acanthichnus alternans Hitchcock 1865, Acanthichnus anguineus Hitchcock 1865, Acanthichnus divaricatus Hitchcock 1865, Acanthichnus punctatus Hitchcock 1865, Acanthichnus saltatorius Hitchcock 1858, and Acanthichnus trilinearis Hitchcock 1865.

Emended diagnosis. A trackway composed of at least two rows of thin, elongate, and straight tracks that are oriented parallel or oblique to the trackway midline. Additional rows of tracks, when present, are not as orderly. Within rows, the tracks are often arranged singly and either one behind the other or en echelon.

Remarks. Hitchcock (1858) differentiated Conopsoides from other ichnotaxa by the presence of raised mounds, or "tubercles", of sediment (Figs. 3a-b). Both Trewin (1994) and Bertling et al. (2006) rejected the presence of mounds as a valid ichnotaxobase. Furthermore, the sediment mounds are seen in other ichnotaxa, including Acanthichnus (Figs. $3 \mathrm{c}-\mathrm{d}, 4-5$ ), and thus mounds cannot be used to differentiate Conopsoides from Acanthichnus. In other respects, the ichnospecies assigned to Conopsoides strongly resemble those within Acanthichnus and Bifurculapes, as outlined below, and thus they are considered junior subjective synonyms and formally synonymized herein.

Hitchcock $(1858,1865)$ erected eight ichnospecies of Acanthichnus, although in 1865 he removed one (Acanthichnus tardigradus) to a new ichnogenus, Pterichnus. Later, Lull (1953) designated Acanthichnus cursorius as the type species. As noted by Dalman and Lucas (2015), the ichnogenus and its included ichnospecies are in need of revision. A thorough revision will be presented elsewhere. For now, revised diagnoses for the ichnogenus and the two ichnospecies to which the Conopsoides trackways are reassigned are presented. 


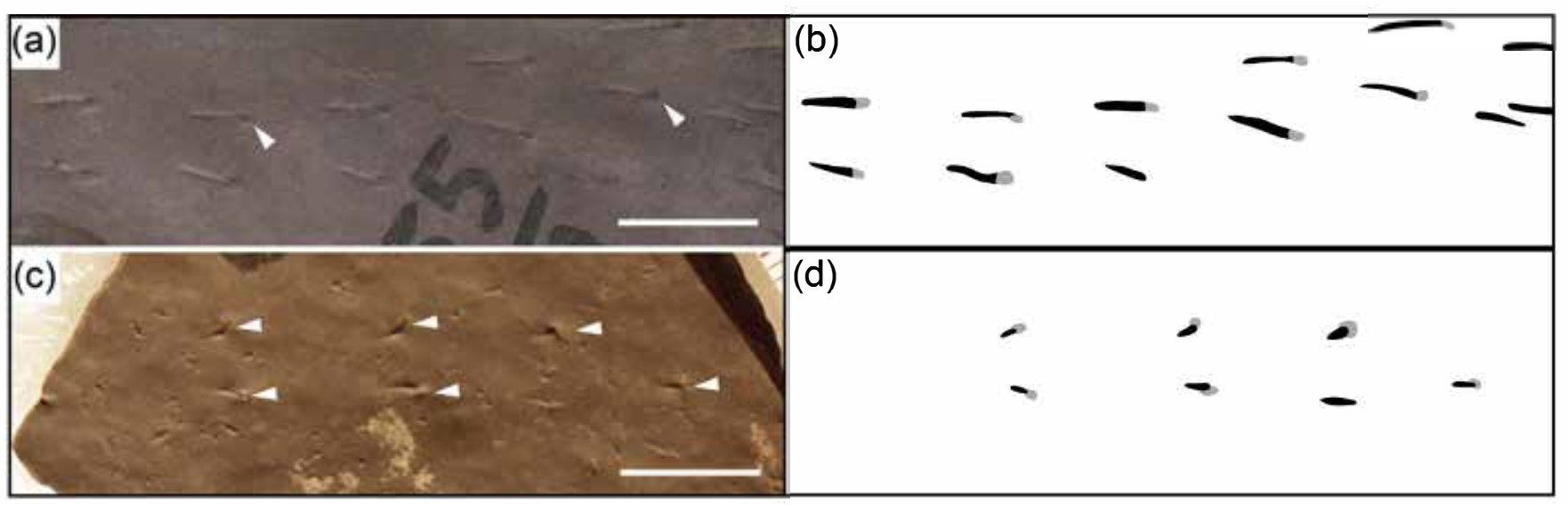

Figure 3. Conopsoides larvalis and Acanthichnus rectilinearis, with interpretive line drawings showing mounds in grey. (a, b) Conopsoides larvalis on ACM.ICH 55/67. Note the mounds, a few of which are arrowed. (c, d) Acanthichnus rectilinearis on ACM.ICH 55/113. Note that many of the tracks also have mounds (arrowed). Scales are $1 \mathrm{~cm}$.

\section{Acanthichnus cursorius Hitchcock 1858}

(Fig. 4)

v. 1858 Acanthichnus cursorius E, Hitchcock, p. 150.

v. 1858 Conopsoides larvalis (in part) E. Hitchcock, p. 152, pl. 29, fig. 6 .

1889 Conopsoides larvalis (in part); C.H. Hitchcock, p. 119.

1915 Conopsoides larvalis (in part); Lull, p. 60-61.

1953 Conopsoides larvalis (in part); Lull, p. 45.

1997 Hamipes molassicus; Bolliger and Gubler, p. 619, fig. 5.

2005 Conopsoides larvalis (in part); Rainforth, p. 840, fig. 5.20.

Occurrence. Upper Triassic Lockatong Formation of the Newark Basin (Fillmore et al. 2017); Lower Jurassic (Hettangian) Turners Falls Formation of the Deerfield Basin (Hitchcock 1858, 1865) and East Berlin Formation of the Hartford Basin (Dalman and Lucas 2015), and OligoceneMiocene Freshwater Molasse of Switzerland (Bolliger and Gubler 1997).

Emended diagnosis. Acanthichnus in which the tracks are arranged in opposite symmetry, are oriented parallel or oblique to the trackway midline (when oblique, the tracks on either side are not parallel, but rather mirror images so that the tracks form open Vs), and have a variable, but often long, stride.

Description. Trackways of this species are between 0.3 and $0.5 \mathrm{~cm}$ wide. The tracks measure 0.2 to $0.6 \mathrm{~cm}$ long and are parallel to, or are rarely oriented at an angle of up to $44^{\circ}$ relative to the midline. Overlap between sets is rare, with the spacing between successive tracks normally ranging from 0.1 to $0.5 \mathrm{~cm}$, but measuring up to $1.8 \mathrm{~cm}$. The stride measures 0.5 to $2.1 \mathrm{~cm}$.

Remarks. The specimens on ACM.ICH 55/57, 55/80, and the shorter one on ACM.ICH 36/25 that Hitchcock (1865) attributed to Conopsoides larvalis, are here considered attributable to Acanthichnus cursorius based on morphological similarity. In particular, the shape and arrangement of tracks of Conopsoides larvalis and Acanthichnus cursorius, both of which are considered valid ichnotaxobases by Trewin (1994) and Bertling et al. (2006), are very similar. Indeed, the specimen on ACM.ICH 55/80 (Figs. 4c-d) exhibits the extremely long stride for which Hitchcock (1858), in part, differentiated Acanthichnus cursorius.

Getty (2018) suggested that traces illustrated and called Hamipes mollasicus by Bolliger and Gubler (1997) should be attributed to Conopsoides since they exhibit large mounds of sediment at the posterior of the tracks. Given that different specimens of Conopsoides are now attributed to either Acanthichnus and Bifurculapes herein, the name for the Swiss trackways described by Bolliger and Gubler should be reconsidered through direct reexamination; but at least some (e.g., Bolliger and Gubler 1997, fig. 5), appear to be attributable to Acanthichnus cursorius as defined herein.

\section{Acanthichnus saltatorius Hitchcock 1858}

(Fig. 5)

$\mathrm{v}^{\star} 1858$ Acanthichnus saltatorius E. Hitchcock, p. 151.

v. 1858 Conopsoides larvalis (in part) E. Hitchcock, p. 152, pl. 30, fig. 4.

1889 Conopsoides larvalis (in part) C.H. Hitchcock, p. 119.

1915 Conopsoides larvalis (in part) Lull, p. 60-61.

1953 Conopsoides larvalis (in part) Lull, p. 45.

2005 Conopsoides larvalis (in part) Rainforth, p. 840, fig. 5.20.

Occurrence. Upper Triassic Lockatong Formation of the Newark Basin (Fillmore et al. 2017); Lower Jurassic (Hettangian), Turners Falls Formation of the Deerfield Basin (Hitchcock 1858, 1865). 


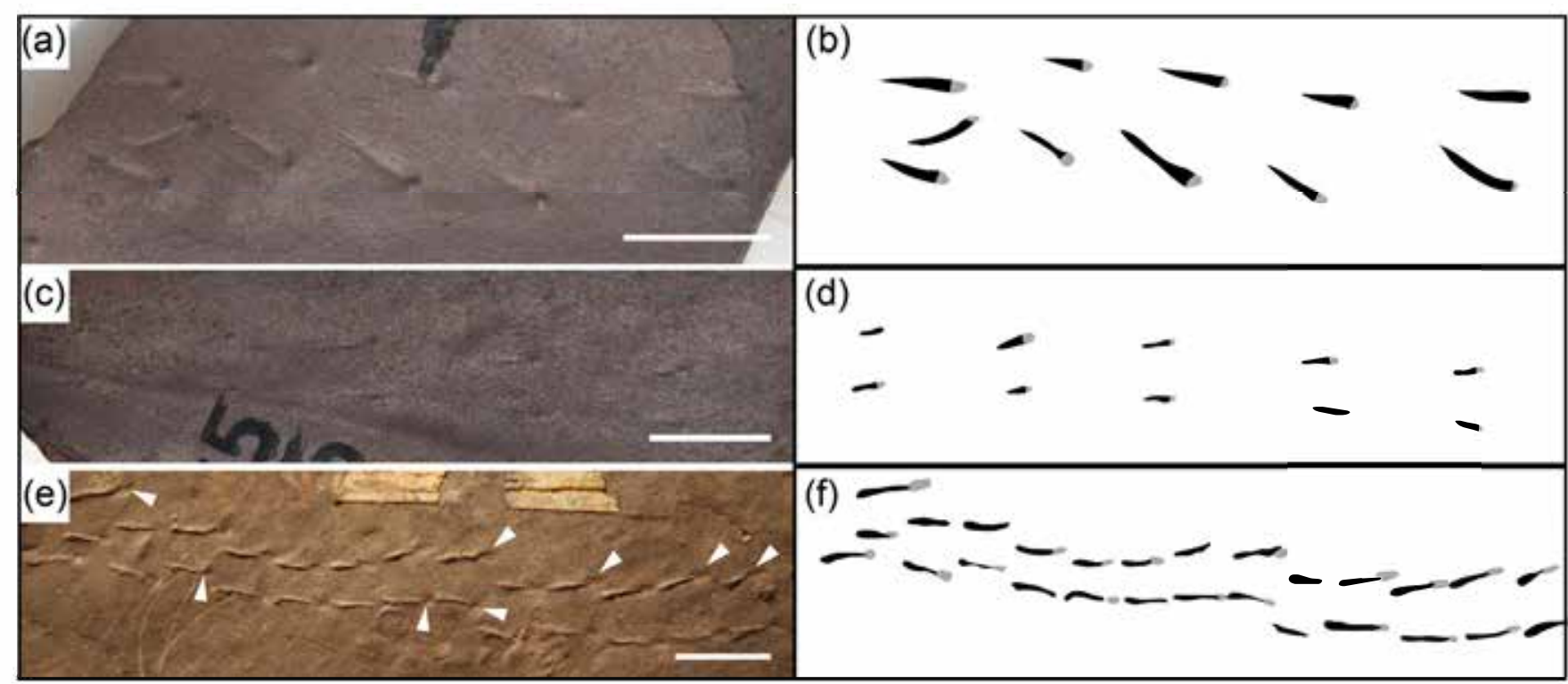

Figure 4. Conopsoides larvalis and Acanthichnus cursorius, with interpretive line drawings showing mounds in grey. (a, b) Conopsoides larvalis on ACM.ICH 55/57. (c, d) Conopsoides larvalis on ACM.ICH 55/80. Note the long stride, which characterizes Acanthichnus cursorius. (e, f) Acanthichnus cursorius on ACM.ICH 36/21. Note that the mounds (arrowed) are preserved in reverse in this natural cast. Scales are $1 \mathrm{~cm}$.

Emended diagnosis. Acanthichnus with opposite symmetry in which the tracks on both sides of the trackway are oriented at the same oblique angle to the trackway midline, and in which successive tracks in the rows are arranged en echelon.

Description. Trackways of this species are approximately 0.3 to $0.5 \mathrm{~cm}$ wide. The tracks are 0.3 to $0.6 \mathrm{~cm}$ long. Tracks are sometimes parallel to the midline, but more often are oriented at an angle that can reach up to $41^{\circ}$ relative to the midline. Set overlap is more common than in Acanthichnus cursorius, and occurs in regions of the trackway in which the tracks parallel the midline. Distances between sets that do not overlap range from 0.1 to $0.6 \mathrm{~cm}$, with the longer distances occurring between sets that are oriented oblique to the midline. The stride measures 0.4 to $1.4 \mathrm{~cm}$.

Remarks. The specimen on ACM.ICH 55/67 (Figs. 3a-b), and the one that crosses the long axis of ACM.ICH 36/25 (Figs. 5a-b), both attributed to Conopsoides larvalis by Hitchcock (1865), are here considered attributable to Acanthichnus saltatorius because they exhibit track pairs that are oblique to the trackway midline as well as an en echelon arrangement of the successive tracks.

\section{Ichnogenus Bifurculapes Hitchcock 1858}

(Fig. 6)

1858 Bifurculapes E. Hitchcock, p. 152.

1865 Conopsoides (in part) E. Hitchcock, p. 15, pl. 6, fig. 4.

1889 Conopsoides (in part) C.H. Hitchcock, p. 119.

1915 Conopsoides (in part) Lull, p. 60-61.

1953 Conopsoides (in part) Lull, p. 45.

1997 Hamipes (in part) Bolliger and Gubler, p. 619, fig. 4.
1975 Conopsoides (in part) Häntzschel, p. W52.

2005 Conopsoides (in part) Rainforth, p. 840, fig. 5.2.

Type species. Bifurculapes laqueatus Hitchcock 1858, designated by Lull (1953, p. 42).

Other species. Bifurculapes scolopendroideus Hitchcock 1858.

Emended diagnosis. Consists of two rows of elongate, straight or crescentic imprints arranged in staggered to alternating symmetry. Tracks vary in length and occur singly or in series of two to three tracks. The two largest tracks are oriented posterolaterally, with their anterior tips forming a line nearly perpendicular to the trackway midline. The longest track is almost always on the outside of the trackway, with the middle length track on the inside, and the smallest between the other two. (Modified from Getty 2018)

Remarks. Hitchcock $(1858,1865)$ established five ichnospecies of Bifurculapes: Bifurculapes curvatus, Bifurculapes elachistotatus, Bifurculapes laqueatus, Bifurculapes scolopendroideus and Bifurculapes tuberculatus. In 1865, Hitchcock removed Bifurculapes tuberculatus from the ichnogenus, arguing that the specimens he based the species on were eroded remnants of more complete trackways. Getty (2016) reviewed Bifurculapes and agreed that Bifurculapes tuberculatus was a preservational variant of a more complete trackway; he also reduced the number of ichnospecies within the ichnogenus to two, Bifurculapes laqueatus and Bifurculapes scolopendroideus, by synonymizing all other ichnospecies with Bifurculapes laqueatus. After observing intergradations 


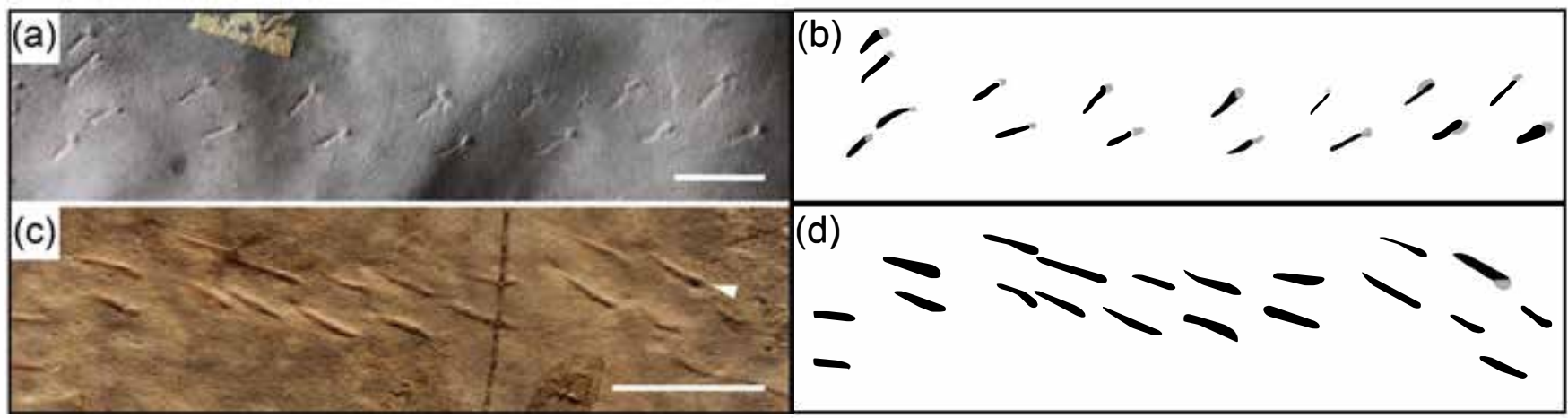

Figure 5. Conopsoides larvalis and Acanthichnus saltatorius, with interpretive line drawings showing mounds in grey. (a, b) Conopsoides larvalis on ACM.ICH 36/25. Note the track sets are at an angle to the trackway midline, which is characteristic of Acanthichnus saltatorius. (c, d) Acanthichnus saltatorius on ACM.ICH 36/34. One track has a mound (arrowed). Scales are $1 \mathrm{~cm}$.

between Bifurculapes laqueatus and Sagittaruis alternans (renamed Camurichnus alternans by Rainforth 2005), Getty (2018) considered the latter a synonym of the former. As with Acanthichnus, the sediment mounds that Hitchcock (1858) used to differentiate Conopsoides also occur in Bifurculapes (Fig. 6).

\section{Bifurculapes laqueatus Hitchcock 1858}

(Fig. 6)

$\mathrm{v}^{\star} 1858$ Bifurculapes laqueatus E, Hitchcock, p. 153. $\mathrm{v}^{\star}$

1865 Conopsoides curtus E. Hitchcock, p. 15, pl. 6, fig. 4.

$\mathrm{v}^{\star} 1865$ Sagittarius alternans E. Hitchcock, p. 16, pl. 6, fig. 3.

1889 Conopsoides curtus C.H. Hitchcock, p. 119

1915 Conopsoides curtus Lull, p. 61.

1915 Sagittarius alternans Lull, p. 61.

1953 Conopsoides curtus Lull, p. 45.

1953 Sagittarius alternans Lull, p. 46.

1997 Hamipes molassicus Bolliger and Gubler, p. 619, fig. 4.

2005 Camurichnus alternans Rainforth, p. 836, fig. 5.16.

2005 Conopsoides curtus Rainforth, p. 842, fig. 5.21.

2005 Conopsoides curtus Rainforth, p. 842, fig. 5.21.

Occurrence. Late Triassic Lockatong Formation of the Newark Basin (Fillmore et al. 2017); Early Jurassic (Hettangian), Turners Falls Formation of the Deerfield Basin (Hitchcock 1858, 1865), East Berlin Formation of the Hartford Basin (Getty 2016); Moenave Formation of the Zuni sag (Lucas et al. 2006; Milner et al. 2009); Early Cretaceous of Spain (de Gilbert et al. 2000); and Oligocene-Miocene Freshwater Molasse of Switzerland (Bolliger and Gubler 1997).

Emended diagnosis. Bifurculapes with single tracks, or series of two to three tracks per series, and a regularly repeating, alternate trackway pattern. (Modified from Getty 2018)
Description. Trackways have external widths from 0.4 to $1.5 \mathrm{~cm}$, and internal widths of 0.1 to $0.6 \mathrm{~cm}$. Tracks are arranged into staggered or alternating series of two to three. Overlap between tracks of successive series is rare. The position of the third track is variable, even within a trackway, where it may be positioned anterior or posterior to the other two tracks, or anywhere between; in a lateral direction, this track may occur close to the trackway midline or between the other two. Individual tracks may be straight or curved, and may have sediment mounds at their anterior end. Outer track lengths range from 0.5 to $5.4 \mathrm{~mm}$, and inner track lengths are from 0.4 to $4.3 \mathrm{~mm}$. Outer tracks are typically oriented posterolaterally at an angle to midline from $0^{\circ}$ to $57^{\circ}$, whereas inner tracks are oriented posterolaterally, posteromedially, or parallel to the trackway midline, with angles of $-37^{\circ}$ to $32^{\circ}$. The stride ranges from 0.2 to $0.8 \mathrm{~cm}$. Medial drags occur rarely. (Modified from Getty 2016 and Getty 2018)

Remarks. Conopsoides curtus is herein considered a junior subjective synonym of Bifurculapes laqueatus because specimens of the former ichnospecies (e.g., ACM.ICH 55/53; Fig. 6) exhibit the sets of two tracks arranged in alternate symmetry that are characteristic of the latter ichnospecies, and because some Bifurculapes laqueatus also exhibits the raised mounds of sediment at the anterior end of the tracks that were originally used to differentiate Conopsoides. Finally, the trackway on ACM.ICH 55/53 is morphometrically very similar to those attributable to Bifurculapes laqueatus. As Fig. 7 shows, when comparing trackway width and track row width, two of the three Conopsoides curtus specimens fall within morphospace occupied by Bifurculapes laqueatus specimens, and the third, which is much larger, falls along the trend line for Bifurculapes laqueatus specimens if they were to get larger.

Hitchcock (1865) listed Conopsoides curtus occurring on ACM.ICH 55/44, 55/53, 55/69, 55/70, and 55/92. The trackways on 55/44,55/70, and 55/92, however, appear to be more similar to Conopsoides larvalis in that they are 


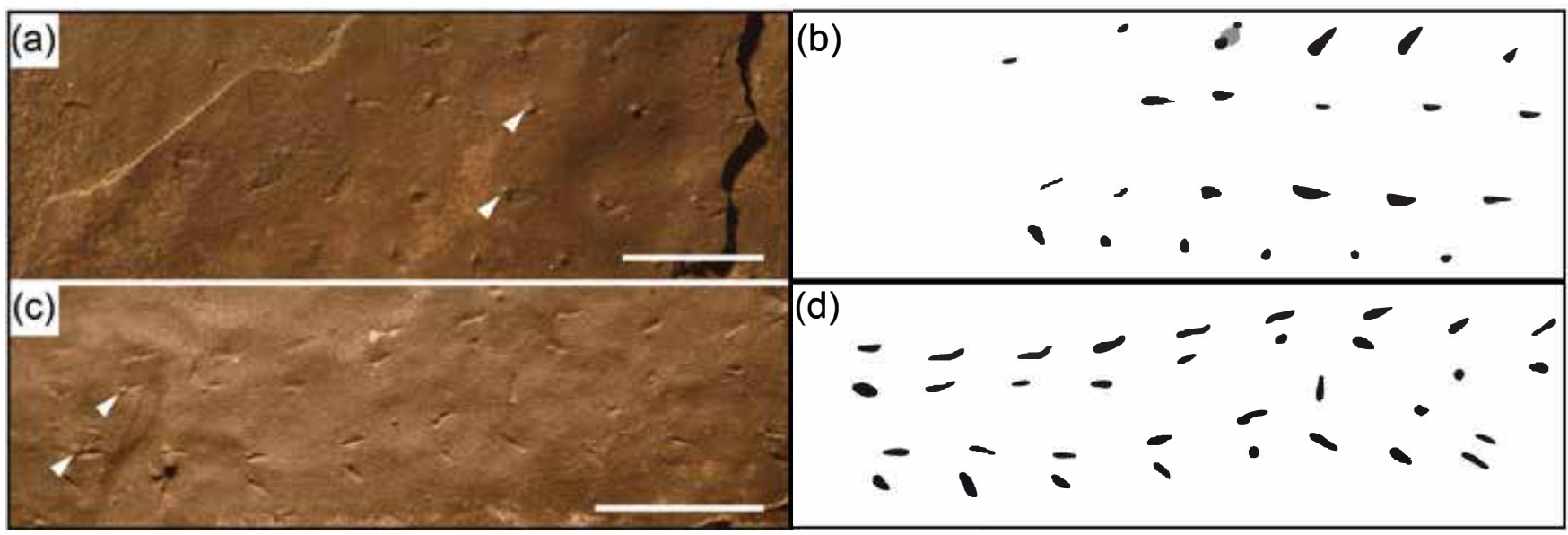

Figure 6. Conopsoides curtus and Bifurculapes laqueatus, with interpretive line drawings. (a, b) Conopsoides curtus lectotype, on ACM.ICH 55/53. (c, d) Bifurculapes laqueatus, on ACM.ICH 55/70. Arrows indicate examples of mounds found in both specimens. All scale bars are $1 \mathrm{~cm}$.

composed of rows of single, rather than double, tracks, and are here assigned to Acanthichnus cursorius.

The Hamipes mollasicus illustrated by Bolliger and $\mathrm{Gu}-$ bler (1997, fig. 5) that have two tracks per series, fit within Bifurculapes laqueatus as defined herein and are at least tentatively reassigned to that ichnospecies until they can be evaluated in person.

\section{DISCUSSION}

\section{Geographic and Stratigraphic Distribution}

Getty $(2016,2018)$ reviewed the geographic and stratigraphic distribution of Bifurculapes, noting that the ichnogenus is known from the Triassic and Jurassic strata of the Newark Supergroup of eastern North America, as well as Jurassic strata of the Zuni Sag in Utah. Fillmore et al. (2017) reported an additional Bifurculapes occurrence from Late Triassic Newark Supergroup rocks in Pennsylvania. The inclusion of those specimens that Hitchcock $(1858,1865)$ called Conopsoides within Bifurculapes does not change the known geographic or stratigraphic distribution of Bifurculapes since all of the specimens that Hitchcock described are from rocks of the same age.

Hitchcock $(1858,1865)$ recorded Acanthichnus from the Turners Falls Formation in the Deerfield Basin of Massachusetts. C.H. Hitchcock (1889) subsequently noted Acanthichnus from the Jurassic Portland Formation in the Hartford Basin of Connecticut. Other researchers (Olsen 1995; Dalman and Lucas 2015; Fillmore et al. 2017) have also reported Acanthichnus from Late Triassic and Early Jurassic rocks of the Newark Supergroup of eastern North America. As with Bifurculapes, the inclusion of some Conopsoides specimens within Acanthichnus does not change the known geographic or stratigraphic distribution of Acanthichnus since it is found in coeval rocks of the Hartford and Deerfield basins.
The Swiss trackways reported by Bolliger and Gubler (1997) therefore represent the first record of Acanthichnus cursorius and Bifurculapes laqueatus from the Miocene of Europe.

\section{Trackmaker}

Hitchcock $(1858,1865)$ considered Conopsoides to be an insect trace, as did Lull $(1915,1953)$ and Häntzschel (1975). Two groups of animals, crustaceans and insects, are usually proposed as potential Bifurculapes trackmakers (see summaries in Getty 2016 and 2018). Getty (2016) preferred an insect origin for Bifurculapes laqueatus from the Hartford and Deerfield basins of Massachusetts, noting similarities to darkling beetle trackways illustrated by Eiseman and Charney (2010). Fillmore et al. (2017) concurred and proposed that Triassic Bifurculapes laqueatus from the Newark Supergroup of Pennsylvania were also made by an insect.

It should be noted, however, that the darkling beetle trackways illustrated by Eiseman and Charney (2010) do have some differences with respect to Bifurculapes laqueatus, including the position of the longest track relative to the others. In Bifurculapes laqueatus, the longest track is almost always on the outside of the trackway, whereas in the modern trackways the longest track is on the inside of the trackway. It seems likely that that these differences are the result of trackmaker behavior, rather than production by very different animals. Specifically, the co-occurrence of $B i$ furculapes laqueatus on slabs with current lineations seems to indicate that the trackway was made under water (Getty in press).

When Hitchcock (1858) established Acanthichnus, he proposed that the ichnogenus could have been the work of either myriapods or crustaceans. By 1865, however, he had examined additional specimens and discovered that some trackways had as many as three tracks on each side of the trackway, which strongly suggested to him that the trackways were made by insects. Lull $(1915,1953)$ agreed, as 


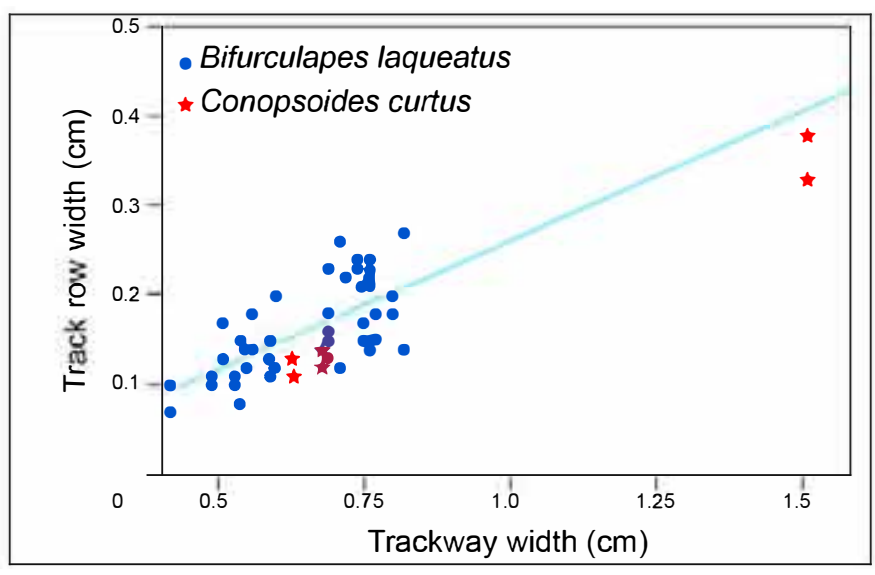

Figure 7. X-Y scatter plot of trackway width versus track row width for the ichnospecies Bifurculapes laqueatus (sensu Getty 2016) and Conopsoides curtus, with trend line.

provisionally did Häntzschel (1975). Dalman and Lucas (2015), however, considered an Acanthichnus trackway associated with the body imprint Cheliceratichnus lockleyi to have been made by a solifugid-like arachnid. Hitchcock $(1858,1865)$ was puzzled by the lateral motion exhibited by the ichnospecies Acanthichnus saltatorius. As with Bifurculapes laqueatus, reexamination of Acanthichnus saltatorius suggests that the unusual morphology exhibited by this ichnogenus is behavioral and could be related to underwater locomotion.

We consider insects the most likely trackmakers for Acanthichnus and Bifurculapes. It is not clear why the number of tracks per series varies. Minter and Braddy (2009) suggested that trackways such as Acanthichnus and Bifurculapes might be incomplete undertracks (see, for example Goldring and Seilacher 1971) of ichnogenera such as Lithographus. The presence of complete sets of three tracks in some Acanthichnus and Bifurculapes trackways indicates that undertracking cannot explain all of the morphological variability among these ichnogenera. Rather, a combination of behavior, sediment consistency, and phylogeny is more likely to explain these morphological differences. Neoichnological experiments are underway to see if this is in fact the case.

\section{Implications for paleodiversity in the Early Jurassic}

In a recent evaluation of invertebrate trace fossils through time, Buatois and Mángano (2018) noted that there was an increase in continental ichnological diversity at the beginning of the Jurassic. The timeframe for the ichnodiversity increase coincides with the age of Newark Supergroup rocks that Edward Hitchcock studied in the Nineteenth Century. Indeed, twelve of Hitchcock's ichnogenera, including Conopsoides, were included in the Buatois and Mángano analysis. Since insects radiated into lakes in the early Mesozoic (Wootton 1988; Ponomarenko 1996; Merritt and Wallace 2003; Sinitshenkova 2003), and since at least seven of the twelve Hitchcock ichnotaxa used in the study were produced by insects in lacustrine environments, the ichnodiversity increase likely represents the radiation of insects into lakes. Which of Hitchcock's ichnogenera actually reflects the biological radiation (and therefore how great the ichnodiversity increase really was) is a question requiring a revision of all of Hitchcock's ichnotaxa. The results of this study indicate that Conopsoides should not have been included, which reduces the number of ichnogenera involved in the observed diversity increase. By contrast, the ichnogenus Lunulipes, which is morphologically distinct from all other of Hitchcock's ichnotaxa and was produced by an aquatic insect (Getty 2017; Getty and Loeb 2018), wasn't included in the Buatois and Mángano (2018) study.

\section{CONCLUSIONS}

Hitchcock (1858) erected the ichnogenus Conopsoides for two different arthropod trackway morphologies that he united based on the presence of sediment mounds adjacent to the tracks. In so doing, he established an ichnological "chimera". The presence or absence of mounds is more likely the result of sediment consistency and undertracking, and therefore wouldn't be considered a valid ichnotaxobase today (Trewin 1994; Bertling et al. 2006; Minter et al. 2007). Furthermore, these features are seen in some examples of other invertebrate ichnotaxa that Hitchcock established, notably Acanthichnus and Bifurculapes. Consequently, the name Conopsoides should be abandoned and its included specimens attributed to three other ichnospecies, Acanthichnus cursorius, Acanthichnus saltatorius and Bifurculapes laqueatus. In particular, specimens of Conopsoides larvalis that have tracks nearly parallel to the trackway midline and an elongate stride are assigned to Acanthichnus cursorius. Specimens of Conopsoides larvalis in which both track rows are oriented at the same oblique angle to the trackway midline, and whose tracks are in an en echelon arrangement, are assigned to Acanthichnus saltatorius. Those trackways named Conopsoides curtus are reassigned to Bifurculapes laqueatus. Species of Acanthichnus and Bifurculapes examined in this study were made by insects, and their morphological differences are most likely the result of trackmaker behavior, sediment consistency, and insect type. The need to revise the ichnotaxonomy of trace fossils is emphasized by their broader application, such as in paleodiversity studies. Only through ichnotaxonomic revisions can excessive splitting, which artificially increases perceived diversity, be eliminated.

\section{ACKNOWLEDGMENTS}

We appreciate the hospitality of Hayley Singleton of the Beneski Museum of Natural History, and Kate Wellspring, formerly of the Beneski Museum of Natural History, for granting us permission to examine the specimens in the 
Hitchcock Ichnology Collection. We thank Neal Alexandrowicz and Donna Cain, both of Collin College, for serving as secondary faculty advisors for John Burnett. This paper benefited from thorough reviews by Spencer Lucas and Matt Stimson.

\section{REFERENCES}

Bertling, M. 2007. What's in a name? Nomenclature, systematics, ichnotaxonomy. In Trace fossils: concepts, problems, prospects. Edited by W. Miller III; Elsevier, New York, pp. 81-91. https://doi.org/10.1016/B978044452949-7/50131-5

Bertling, M., Braddy, S.J., Bromley, R.G., Demathieu, G.R., Genise, J., Mikuláš, R., Nielsen, J.K., Nielsen, S.S., Rindsberg, A.K., Schlirf, M., and Uchman, A. 2006. Names for trace fossils: a uniform approach. Lethaia, 39, pp. 265286. https://doi.org/10.1080/00241160600787890

Bolliger, T. and Gubler, T. 1997. Arthropodenlaufspuren von Hochdorf (LU) und weitere Arthropodennachweise aus der Oberen Süsswassermolasse der Schweiz. Eclogae Geologicae Helvetiae, 90, pp. 617-627.

Bromley, R.G. 1996. Trace fossils. Biology, taphonomy, and applications. Chapman and Hall, London, 361 p. https:// doi.org/10.1007/978-1-4899-2875-7

Buatois, L and Mángano, M.G. 2011. Ichnology. Organism-substrate interactions in space and time. Cambridge University Press, New York, 358 p. https://doi. org/10.1017/CBO9780511975622

Buatois, L.A. and Mángano, M.G. 2018. The other biodiversity record: innovations in animal-substrate interactions through geologic time. GSA Today, 28, pp. 4-10. https:// doi.org/10.1130/GSATG371A.1

Dalman, S.G. and Lucas, S.G. 2015. Lower Jurassic arthropod resting trace from the Hartford Basin of Massachusetts, USA. Ichnos, 22, pp. 177-182. https://doi.org/10.10 80/10420940.2015.1059337

de Gilbert, J.M., Fregenal-Martínez, M.A., Buatois, L.A., and Mángano, M.G., 2000. Trace fossils and their palaeo ecological significance in Lower Cretaceous lacustrine conservation deposits, El Montsec, Spain. Paleogeography, Palaeoclimatology, Palaeoecology, 156, pp. 89-101. https://doi.org/10.1016/S0031-0182(99)00133-9

Eiseman, C. and Charney, N. 2010. Tracks \& sign of insects and other invertebrates: a guide to North American species. Stackpole Books, Mechanicsburg, $582 \mathrm{p}$.

Fillmore, D.L., Szajna, M.J., Lucas, S.G., Hartline, B.W., and Simpson, E.L. 2017. Ichnology of a Late Triassic lake margin: the Lockatong Formation, Newark Basin, Pennsylvania. New Mexico Museum of Natural History and Science Bulletin, 76, pp. 1-107.

Getty, P.R. 2016. Bifurculapes Hitchcock 1858: a revision of the ichnogenus. Atlantic Geology, 52, pp. 247-255. https://doi.org/10.4138/atlgeol.2016.013

Getty, P.R. 2017. Lunulipes, a replacement name for the trace fossil Lunula Hitchcock 1865, preoccupied. Journal of Pa- leontology, 91, p. 577. https://doi.org/10.1017/jpa.2017.13 Getty, P.R. 2018. Revision of the Early Jurassic arthropod trackways Camurichnus and Hamipes. Boletín de la Sociedad Geológica Mexicana, 70, pp. 281-292. https://doi. org/10.18268/BSGM2018v70n2a1

Getty, P.R. In press. Evidence that the fossil insect trackway Bifurculapes laqueatus Hitchcock, 1858 was made underwater. Acta Geologica Polonica.

Getty, P.R. and Loeb, S.B. 2018. Aquatic insect trackways from Jurassic playa lakes: reinterpretation of Lunulipes obscurus (Hitchcock, 1865) based on neoichnological experiments. Palaeodiversity, 11, pp. 1-10. https://doi. org/10.18476/pale.11.a1

Goldring, R. and Seilacher, A. 1971. Limulid undertracks and their sedimentological implications. Neues Jahrbuch fur Paläontologie und Geologie Abhandlungen, 137, pp. 422-442.

Goldring, R., Pollard, J.E., and Seilacher, A. 1997. Naming trace fossils. Geological Magazine, 134, pp. 265-268. https://doi.org/10.1017/S0016756897006717

Goldstein, D.H. and Getty, P.R. 2017. Hitchcock's treptichnid trace fossils (Jurassic, Massachusetts, USA): conflicting interpretations in the "Age of Fucoids". Bollettino della Società Paleontologica Italiana, 56, pp. 109-116.

Häntzschel, W. 1975. Trace fossils and problematica. In Treatise on invertebrate paleontology, part. W. Miscellanea, supplement I. Edited by C. Teichert. Geological Society of America and University of Kansas Press, 269 p.

Hitchcock, E. 1858. Ichnology of New England. A report on the sandstone of the Connecticut Valley, especially its fossil footmarks. William White, Boston, $220 \mathrm{p}$.

Hitchcock, E. 1865. Supplement to the ichnology of New England. A report to the Government of Massachusetts, in 1863; Wright and Potter, Boston. 96 p.

Hitchcock, C.H. 1889. Recent progress in ichnology. Proceedings of the Boston Society of Natural History, 24, pp. 117-127.

Hubert, J.F. 1978. Paleosol caliche in the New Haven Arkose, Newark Group, Connecticut. Paleogeography, Palaeoclimatology, Palaeoecology, 24, pp. 151-168. https://doi. org/10.1016/0031-0182(78)90004-4

Keighley, D.G. and Pickerill, R.K. 1998. Systematic ichnology of the Mabou and Cumberland groups (Carboniferous) of western Cape Breton Island, eastern Canada, 2: surface markings. Atlantic Geology, 34, pp. 83-112. https://doi.org/10.4138/2041

Knaust, D. 2012. Trace fossil systematics. In Developments in sedimentology, volume 64. Trace fossils as indicators of sedimentary environments. Edited by D. Knaust and R.G. Bromley. Elsevier, Burlington, Massachusetts, pp. 79-101. https://doi.org/10.1016/B978-0-444-53813-0.00003-4

Lucas, S.G., Lerner, A.J., Milner, A.J., and Lockley, M.G. 2006. Lower Jurassic invertebrate ichnofossils from a clastic lake margin, Johnson Farm, southwestern Utah. In The Triassic-Jurassic terrestrial transition. Edited by J.D. Harris, S.G. Lucas, J.A. Spielmann, M.G. Lockley, A.R.C. Milner, and J.I. Kirkland. New Mexico Museum of Natural 
History and Science Bulletin 37, pp. 128-136.

Lucas, S.G., Voigt, S., Lerner, A.J., and Rainforth, E.C. 2013. Sphaerapus, a poorly known invertebrate trace fossil from nonmarine Permian and Jurassic strata of North America. Ichnos, 20, pp. 142-152. https://doi.org/10.1080/1042 0940.2013 .817406

Lull, R.S. 1915. Triassic life of the Connecticut Valley. State of Connecticut, State Geological and Natural History Survey Bulletin 24, 285 p. https://doi.org/10.5962/bhl.title.70405

Lull, R.S. 1953. Triassic life of the Connecticut Valley, revised. State of Connecticut, State Geological and Natural History Survey Bulletin 81, 336 p.

Merritt, R.W. and Wallace, J.B. 2003. Aquatic habitats. In Encyclopedia of insects. Edited by V.H. Resh and R.T. Cardé. Academic Press, New York, pp. 45-56.

Milner, A.R.C., Harris, J.D., Lockley, M.G., Kirkland, J.I., and Matthews, N.A. 2009. Bird-like anatomy, posture, and behavior revealed by an Early Jurassic theropod dinosaur resting trace. PLoS ONE 4: e4591. https://doi. org/10.1371/journal.pone.0004591

Minter, N.J. and Braddy, S.J. 2009. Ichnology of an Early Permian intertidal flat: the Robledo Mountains Formation of southern New Mexico, USA. Special Papers in Palaeontology, 82, pp. 5-107.

Minter, N.J., Braddy, S.J., and Davis, R.B. 2007. Between a rock and a hard place: arthropod trackways and ichnotaxonomy. Lethaia, 40, pp. 365-375. https://doi.org/10.1111/ j.1502-3931.2007.00035.x

Minter, N.J., Lockley, M.G., Huh, M. Hwang, K.-G., and Kim, J.Y. 2012. Lithographus, an abundant arthropod trackway from the Cretaceous Haenam tracksite of Korea. Ichnos, 19, pp. 115-120. https://doi.org/10.1080/104 20940.2011.625756

Olsen, P.E. 1978. On the use of the term Newark for Triassic and Early Jurassic rocks of eastern North America. Newsletters on Stratigraphy, 7, pp. 90-95. https://doi. org/10.1127/nos/7/1978/90

Olsen, P.E. 1986. A 40-million-year lake record of early Mesozoic orbital climactic forcing. Science, 234, pp. 842848. https://doi.org/10.1126/science.234.4778.842

Olsen, P.E. 1995. Paleontology and paleoenvironments of Early Jurassic age strata in the Walter Kidde Dinosaur Park (New Jersey, USA). In Field Guide and Proceedings of the Twelfth Annual Meeting of the Geological Association of New Jersey. Edited by J.E.B. Baker. William Patterson College, New Jersey, pp. 156-190.

Olsen, P.E. 1997. Stratigraphic record of the early Mesozoic breakup of Pangea in the Laurasia-Gondwana rift system. Annual Review of Earth and Planetary Sciences, 25, pp. 337-401. https://doi.org/10.1146/annurev.earth.25.1.337

Olsen, P.E., McDonald, N.G., Huber, P, and Cornet, B. 1992. Stratigraphy and paleoecology of the Deerfield Rift Basin (Triassic-Jurassic, Newark Supergroup), Massachusetts. In Guidebook for field trips in the Connecticut Valley region of Massachusetts and adjacent states. Edited by P. Robinson and J.B Brady. New England Intercollegiate
Geological Conference, pp. 488-535.

Olsen, P.E., Schlische, R.W., and Fedosh, M.S. 1996. 580 ky duration of the Early Jurassic flood basalt event in eastern North America estimated using Milankovitch cyclostratigraphy. In The Continental Jurassic. Edited by M. Morales. Museum of Northern Arizona Bulletin 60, pp. $11-22$.

Osgood, R.G. 1970. Trace fossils of the Cincinnati area. Palaeontographica Americana, 6, pp. 276-444.

Parrish, J.T. 1993. Climate of the supercontinent Pangea. Journal of Geology, 101, pp. 215-233. https://doi. org/10.1086/648217

Pickerill, R.K. 1994. Nomenclature and taxonomy of invertebrate trace fossils. In The palaeobiology of trace fossils. Edited by S.K. Donovan; John Wiley \& Sons, London, pp. 3-42.

Ponomarenko, A.G. 1996. Evolution of continental aquatic ecosystems. Paleontological Journal, 30, pp. 705-709.

Rainforth, E.C. 2005. Ichnotaxonomy of the fossil footprints of the Connecticut Valley (Early Jurassic, Newark Supergroup, Connecticut and Massachusetts). Unpublished Ph.D. thesis, Columbia University, New York, 1301 p.

Rasband, W.S. 1997-2014. ImageJ: U.S. National Institutes of Health, Bethesda, Maryland, USA. URL $<\underline{\text { http://im- }}$ agej.nih.gov/ij/>, 6 March 2015.

Rindsberg, A.K. 2012. Ichnotaxonomy: finding patterns in a welter of information. In Developments in sedimentology, volume 64; Trace fossils as indicators of sedimentary environments. Edited by D. Knaust and R.G. Bromley. Elsevier, Burlington, Massachusetts, pp. 45-78. https://doi. org/10.1016/B978-0-444-53813-0.00002-2

Schlische, R.W. and Olsen, P.E. 1990. Quantitative filling model for continental extensional basins with applications to early Mesozoic rifts of eastern North America. The Journal of Geology, 98, pp. 135-155. https://doi. org/10.1086/629390

Sinitshenkova, N.D. 2003 Main ecological events in aquatic insects [sic] history. Acta Zoologica Cracoviensia, 46 (suppl. - Fossil Insects), pp. 381-392.

Tanner, L.H. and Lucas, S.G. 2015. The Triassic-Jurassic strata of the Newark Basin, USA: a complete and accurate astronomically-tuned timescale? Stratigraphy, 12, pp. 47-65.

Trewin, N.H. 1994. A draft system for the identification and description of arthropod trackways. Palaeontology, 37, pp. 811-823.

Weems, R.E., Tanner, L.H. and Lucas, S.G. 2016. Synthesis and revision of the lithostratigraphic groups and formations in the Upper Permian?-Lower Jurassic Newark Supergroup of eastern North America. Stratigraphy, 13, pp. 111-153.

Wootton, R.J. 1988. The historical ecology of aquatic insects: an overview. Palaeogeography, Palaeoclimatology, Palaeoecology, 62, pp. 477-492. https://doi.org/10.1016/00310182(88)90068-5

Editorial responsibility: Robert A. Fensome 